\title{
2.4 Теоретичні основи концепції педагогічного впливу на розвиток професіоналізму майбутніх вихователів
}

Дошкільна освіта $є$ первинним елементом освітньої системи України. Адже, основа майбутньої особистості закладається ще у ранньому віці. Саме тому, виховання здорової та компетентної особистості, забезпечення якісної та доступної дошкільної освіти є головними пріоритетами сучасної політики держави. Дійсно, дошкілля $є$ тим самим фундаментом сучасної системи безперервної освіти, який вкрай необхідно зробити міцним. Відтак, дошкільна освіта має трансформуватися в гнучку, науково обгрунтовану й варіативну систему, яка реалізує державне замовлення та відповідає запитам споживачів дошкільних освітніх послуг, що належать до різних соціальних груп.

Спрямованість дошкільної освіти на кінцевий педагогічний результат всебічний розвиток особистості дитини та забезпечення іiї успішності на наступних ступенях навчання, передбачає високий рівень професіоналізму вихователів закладів дошкільної освіти.

У зв'язку з цим, модернізація системи освіти в умовах сьогодення висуває нові вимоги до професійної діяльності педагогів дошкільних навчальних закладів. Їх зміст полягає в забезпеченні розвитку інноваційних процесів та їх запровадження в професійну діяльність. Ці вихідні концептуальні положення закладено у таких документах, як: Державна національна програма «Освіта» («Україна XXI століття») (1994р.) Законах України «Про освіту» (1996 р.), «Про дошкільну освіту (2003р.), Національна стратегія розвитку освіти в Україні на 2012-2021 pp. (2012 р.), галузева Концепція розвитку неперервної педагогічної освіти (2013 р.), Концепція Державної цільової програми розвитку дошкільної освіти на період до 2017 року.

Враховуючи наведені вихідні положення, визначимо сили, які, на нашу думку, зумовлюють прогресивний розвиток особистості вихователя. По-перше, це висока внутрішньо диференційована вмотивованість у здійсненні продуктивної педагогічної праці; по-друге, оформлення власної ціннісно- 
THEORETICAL FOUNDATIONS OF THE FUNCTIONING OF EDUCATION. WAYS TO

IMPROVE THE EFFECTIVENESS OF EDUCATIONAL ACTIVITIES

смислової свідомості; по-третє, оптимізація культурно-освітнього простору, який сприятиме збереженню соціальної цілісності та особистісної самореалізації фахівця дошкільної педагогіки.

Одним із базових, інтегрувальних складників готовності майбутнього педагога-вихователя є мотивація до професійного самовдосконалення, адже саме вона забезпечуватиме прогресивний розвиток особистості відповідно до вимог професійної діяльності.

Тобто, зі зміною мотиваційної сфери майбутнього фахівця дошкільної освіти починає знаходити своє відображення ціннісне ставлення до професіоналізму педагогічних працівників, поява більшої здатності мобілізувати себе на подолання труднощів, більш об'єктивне оцінювання своїх сильних i слабких сторін, уміння аналізувати успіхи, невдачі, можливості, творчий підхід та ініціативність в професійній діяльності, сформованість емоційноспонукальних чинників самоосвітньої діяльності.

Метою діяльності вихователів закладів дошкільної освіти є досягнення ними максимально можливого рівня підготовленості до акмесинергетичного професійного самовдосконалення, що, своєю чергою, детермінується актуалізацією рефлексивно-аксіологічного потенціалу.

Таким чином, орієнтуючись на реалізацію незадіяного в роботі особистісного потенціалу педагогів-вихователів, очікується їхня спрямованість на продуктивну професійну діяльність саме від процесу ціннісно-смислової самоорганізації: набуття мотивів розвитку професіоналізму, усвідомлення сутнісних екзистенціальних характеристик професійної діяльності, прояв суб'єктної активності стосовно себе, глибоке і всебічне самопізнання, критичне рефлексування власного життєвого шляху.

Зауважимо, що потреба майбутнього вихователя в розвитку педагогічного професіоналізму визначається актуалізацією певних характеристик цього процесу (рівень розвитку самосвідомості, самовизначення, самопрогнозування, самовиявлення тощо) й забезпечується базовим рівнем особистісного саморозвитку, насиченістю життя особистості педагога та виникає при зміні 
THEORETICAL FOUNDATIONS OF THE FUNCTIONING OF EDUCATION. WAYS TO IMPROVE THE EFFECTIVENESS OF EDUCATIONAL ACTIVITIES

змістової структури індивідуальної свідомості й трансформації смислових утворень. У зв’язку з цим, психолого-педагогічним умовами, що забезпечуватимуть успішність цього процесу, вважаємо: наявність чітко усвідомленої мети самоздійснення (врахування особистісних, професійних i життєвих цілей) як орієнтира самовдосконалення та активної життєвої стратегії якісних самозмін.

Виходячи $з$ того, що сьогодні в центр будь-яких перетворень поставлено особистість, то існуюча система вищої освіти ще 3 більшою оперативністю покликана реагувати й перебудовувати свою діяльність відповідно до людиноцентристського підходу: визнання людини як найвищої соціальної цінності, повага до особистості, іiі гідності, інтересів, створення оптимальних умов для прогресивного розвитку творчої індивідуальності.

Навчання педагогічних кадрів на засадах гуманізму як фундаментальних загальнолюдських цінностей гарантує забезпечення гуманістичного самовизначення вихователів, набуття ними теоретичних знань і умінь, так необхідних для успішної реалізації свого гуманістичного потенціалу у професійній діяльності. Адже вершиною гуманоцентризму $\epsilon$ реалізація принципу людяності. Навіть у системі післядипломної освіти є потреба нагадувати викладачам про особливості індивідуального підходу до слухачів. Будь-яке знання, за яким прийшла людина, може бути сприятливим за умов розуміння особливостей iї індивідуальних інтересів та уподобань, iі ідеалів та мpiï.

Так, А. Роботова зазначає, що викладач є найкомпетентнішим фахівцем, який володіє мистецтвом перетворення людини. Він активно, повсякденно, цілеспрямовано впливає на розум і знання особистості, рухаючи їі від темряви до світла; почуття, за допомогою яких пробуджується й розвивається позитивне ставлення до прекрасного, доброго, довічного [114, с. 18].

Розмірковуючи подібним чином, ми дійшли висновку, що гуманоцентризм $\epsilon$ системою взаємосприятливих, доброзичливих, гармонійних людських відносин, основу яких складає людяність, справедливість, віра, доброта. Тому 
THEORETICAL FOUNDATIONS OF THE FUNCTIONING OF EDUCATION. WAYS TO

IMPROVE THE EFFECTIVENESS OF EDUCATIONAL ACTIVITIES

саме гуманоцентризм має бути визнаним сучасною фундаментальною парадигмою педагогічної діяльності, що потребує концептуальної розвиненості й інституціалізації.

Тому, наступним закономірним кроком у побудові концепції педагогічного впливу на розвиток професіоналізму педагогів-вихователів закладів дошкільної освіти виступатиме висвітлення такого явища як фасилітація (facilitate полегшувати, сприяти, допомагати, створювати сприятливі умови). Під фасилітацією в системі вищзӧ освіти розуміють недирективну форму педагогічного впливу, що надихає та стимулює майбутніх вихователів до особистісно-професійного зростання.

Цілі, завдання та принципи вищої освіти висувають високі вимоги до викладача університету. Це - педагог, який має дослідницькі, аналітичні та викладацькі здібності, вміє практично інтерпретувати сучасні наукові досягнення, насамкінець, володіє даром професійного передбачення.

В умовах глибоких концептуальних змін у системі підготовки i педагогічних кадрів та їі корегування, задачі діяльності викладача мають бути зорієнтовані на:

- гуманізацію відносин в освітньому просторі, забезпечення просування та розвитку в рефлексивно-інноваційному середовищі ціннісносмислових орієнтирів: базових загальнолюдських цінностей добра, любові, свободи, гідності, міжнаціональної злагоди, толерантності й терпимості;

- підготовку майбутніх вихователів до адаптації своїх індивідуальнопсихологічних особливостей у відповідності 3 вимогами до педагогічної діяльності, безперервного розвитку соціально-моральних та інших властивостей особистості;

- організацію навчання на базі яскравих i талановитих фахівців дошкільної освіти області, які консультують або навчають на власному досвіді у своєму закладі дошкільної освіти;

- $\quad$ підвищення рівня загальнодидактичної та методичної підготовленості педагога-вихователя; 
THEORETICAL FOUNDATIONS OF THE FUNCTIONING OF EDUCATION. WAYS TO IMPROVE THE EFFECTIVENESS OF EDUCATIONAL ACTIVITIES

- діагностику специфічних тенденцій в освітньому середовищі, професійних та особистісних змін;

Ми дійшли висновку, що інтенсифікація розвитку педагогічного професіоналізму майбутніх вихователів закладів дошкільної освіти залежить від багатьох чинників, у тому числі й від того, наскільки ефективно буде організована фасилітативна взаємодія між суб' єктами освітнього процесу.

Слід зазначити, що здатність викладачів до фасилітуючого спілкування дає змогу здійснювати максимальне наближення до конкретних потреб майбутніх педагогів-вихователів, що надихає і мотивує їх до інтенсивного, свідомого самооновлення у відповідності до особистісно пріоритетних сенсів самоорганізації, тим самим актуалізуючи процес його спрямованого i продуктивного розвитку професіоналізму.

Психолого-педагогічне пояснення такого екофасилітативного підходу знаходимо в наукових доробках Т. Сущенко, яка розглядає це явище як процес взаємного духовного збагачення викладачів і студентів в умовах психологічнокомфортних відносин, інтелектуальної співтворчості й бездоганної діалогічної культури. На думку, дослідниці, така взаємодія є складовою зазначеного процесу і являє собою цілеспрямовану діяльність, що передбачає прагнення до зближення та злагоди між учасниками процесу; уміння викладачів запропонувати студентам таку форму життєтворчості, яка захоплює, дивує та вражає; таке ставлення до людини, яке сприяє розкриттю його самобутності, вихід з простору вимушеного спілкування й поетапний розвиток духовного потенціалу особистості педагога $[115$, c. 463$]$.

Підсумовуючи вищезгадане, зазначимо, що дотримання викладачем у навчальному процесі пріоритетних фасилітуючих принципів створює особливу атмосферу духовної критики, взаємної поваги та підтримки, що сприяє максимальній розкутості та самовираженню курсантів, а педагогічний процес у такому разі природно й непомітно для студенрів перетворюється в науковий пошук. Зробимо спробу доповнити наявні концептуальні підходи перспективою ще одного напряму, який надасть змогу по-іншому підійти до розуміння 
THEORETICAL FOUNDATIONS OF THE FUNCTIONING OF EDUCATION. WAYS TO

IMPROVE THE EFFECTIVENESS OF EDUCATIONAL ACTIVITIES

категорії професіоналізму вихователя закладу дошкільної освіти й оцінки його педагогічної діяльності. Загальновідомим є той факт, що освіта, яку здобуває фахівець 3 опорою на особистісний досвід, $є$ найбільш ефективною i продуктивною формою навчання. Освіта, яку отримує майбутній вихователь в процесі навчання передбачає оволодіння теоретичними знаннями, професійними вміннями та навичками, педагогічними якостями, які педагог має показати у процесі своєї подальшої професійної діяльності. Педагогічна вища освіта майбутніх вихователів має бути націлена на збільшення кількості годин практики, як навчальної так і виробничої, адже під час практики відбувається занурення майбутніх педагогів у світ дошкільної освіти, здобувачі вищої освіти навчаються встановлювати контакт 3 дітьми, планувати освітню діяльність, організовувати освітній процес, здійснювати навчання та виховання дошкільників. Викладачі закладу вищої освіти як керівники практики мають здійснювати супровід, підтримку майбутніх педагогів, надавати відповідні консультації, методичні рекомендації. Саме за умови злагодженої діяльності студентів та викладачів може бути позитивний результат навчання. Враховуючи сучасні зміни в освіті та зміни ролей педагогів, викладач має бути i консультантом, організатором, фасилітатором, ментором, коучем тощо. Викладач має бути партнером для студента у навчанні, але при цьому мати свій авторитет серед студентської спільноти.

Враховуючи сучасні зміни в освіті викладач має використовувати нові підходи до навчання студентів. Враховуючи стрімкий розвиток інформаційних технологій сучасний освітній процес вже не сприймається здобувачами освіти якщо він відбувається без використання проектору, мультимедійної дошки, різноманітних онлайн-технологій. Також враховуючи зміни у розвитку молодого покоління викладач має використовувати на заняттях інтерактивні вправи, ділові ігри, різноманітні форми практичної роботи студентів. Сучасні здобувачі освіти прагнуть щоб іх думка була почута, а ідеї - реалізовані. Тому в організації 
THEORETICAL FOUNDATIONS OF THE FUNCTIONING OF EDUCATION. WAYS TO

IMPROVE THE EFFECTIVENESS OF EDUCATIONAL ACTIVITIES

освітнього процесу із молодими вихователями постає питання про створення умов навчального середовища.

Наше бачення розв’язання проблеми диференціації полягає у необхідності створення оптимальних умов для творчого та професійного розвитку особистості майбутнього вихователя, реалізації особистісно орієнтованої моделі організації навчальної роботи, яка передбачає відмінності у змісті та формах навчання, визначення рівнів навчання та навченості, реалізації своїх потенційних задатків і можливостей під час розроблення індивідуальних програм саморозвитку тощо.

Відтак, стає зрозумілим, що зміст навчального матеріалу та форми його реалізації необхідно обирати залежно від початкового рівня компетентності студента, його психологічних особливостей, індивідуальних потреб, сформованих практичних навичок. Ми виходимо з усвідомлення диференціаціï прощесу навчання як полівекторності підходів (індивідуальних, групових, колективних) до реалізації змісту освіти та досягнення фундаментальної мети: активне якісне перетворення майбутнім педагогом-вихователем власного внутрішнього світу, орієнтуючись на високі професійні успіхи й перемоги.

Науково-методичним джерелом і програмним координатором цих якісних змін стають саме викладачі вищої освіти, які актуалізують необхідність організації педагогічного супроводу становлення професіоналізму майбутніх вихователів. Виходячи з цих позицій, вважаємо, що квінтесенцією у забезпеченні якості освіти має той факт, яким чином побудовано й організовано навчальний процес, наскільки застосовувана організаційна структура навчання відповідає іï цілям, змісту, насамперед, потребам і тих, кого навчають, і тим, хто навчає.

Досить впливовим аргументом на користь впровадження в систему вищої освіти є технологія концентрованого навчання - особлива технологія організації навчального процесу, за якої увага викладачів зосереджується на більш глибокому вивченні кожної дисципліни за рахунок об’єднання занять, скорочення кількості дисциплін, які вивчаються паралельно упродовж навчального дня, тижня та більш крупних одиниць навчання (Г. Ібрагімов). Сутнісними ознаками такої технології є: подолання поліпредметності 
THEORETICAL FOUNDATIONS OF THE FUNCTIONING OF EDUCATION. WAYS TO

IMPROVE THE EFFECTIVENESS OF EDUCATIONAL ACTIVITIES

навчального дня або тижня; разова тривалість вивчення дисципліни або іï окремого модуля; неперервність процесу пізнання та його цілісність; укрупнення змісту та форм організації навчального процесу; інтенсифікація педагогічного процесу по кожній дисципліні [116, с. 15].

Таке бачення навчання майбутніх педагогів дошкільної освіти зумовлене низкою переваг запропонованої технології перед існуючими, по-перше, нейрофізіологічною основою $є$ закон домінанти або домінантний механізм роботи мозку, який забезпечує природну потребу в інтелектуальній активності; nо-друге, психофізіологічним базисом слугують закономірності динаміки працездатності особистості; по-трете, можливістю за мінімально можливий навчальний час забезпечити ефективне засвоєння максимально можливого матеріалу (потужна активізація пізнавальної діяльності); по-четверте, глибоке занурення (зосередження зусиль) до певної дисципліни (або модуля), спрямоване на цілісність педагогічного процесу. На нашу думку, такі теоретичні основи (нейрофізіологічні, психофізіологічні, психологічні, дидактичні) концентрованого навчання $€$ рушійними силами адаптації післядипломної педагогічної освіти до нових умов інтенсивного розвитку взагалі, й оновлення всієї системи безперервного розвитку педагогічних кадрів, зокрема.

3 огляду на те, що в умовах сьогодення система дошкільної освіти перейшла на новий етап розвитку - оновлення нормативної бази, формування й розвиток мережі ЗДО, які забезпечують гнучкість та розмаїття наданих послуг: міні-садки, групи короткочасного утримання, дошкільні навчальні заклади санаторного типу (оздоровчі), сімейні дошкільні навчальні заклади, ігрові центри, лекотеки та ін. - всі ці зміни передбачають активну участь вихователів у відборі методів та прийомів роботи 3 дітьми, розробці та адаптації змісту відповідно до особливостей конкретного дитячого колективу, врешті-решт наявність професійної мобільності.

На нашу думку, особливе місце займає позиція В. Кременя, який акцентує увагу на тому, що «людина інноваційного мислення, інноваційного типу культури, здатної до інноваційного типу діяльності - лише така людина може 
бути конкурентоспроможною, такі люди можуть скласти мобільне суспільство, мобільну націю. Тому формування інноваційної людини - нагальне завдання освіти» $[117$, с. 16$]$.

У зв'язку з цим слід відзначити важливість та актуальність думки В. Андрущенка стосовно того, що «чим вищий рівень розвитку соціальнопрофесійної мобільності педагогів, тим більш інтенсивно вони залучені в інноваційний процес, оскільки новації і мобільність в сучасних освітніх закладах - це два чинники, взаємопов'язаних і взаємовпливаючих один на одного. При цьому соціально-професійну мобільність можна розглядати як засіб, спосіб і результат освоєння новацій педагогом, що свідомо включається в інноваційну педагогічну діяльність і фундаментально підготовлений до здійснення цього процесу. Це об'єктивно посилює вимоги до якості професійної підготовки на етапі навчання, де, власне, і розкривається інноваційний потенціал особистості педагога як «суб'єктивне джерело зародження інновацій» у професійній діяльності, як «особливість стану індивідуальної свідомості педагога, його відкритість до сприйняття нового, незалежність від стереотипів та шаблонів» [118, с. 61].

Отже, педагогічний вплив та його концепції мають велике значення у формуванні майбутнього конкурентноспроможного, сучасного, професійного вихователя закладу дошкільної освіти. 